\title{
Evaluation of phytotoxicity of three organic amendments to collard greens using the seed germination bioassay
}

\author{
Tesfamichael H. Kebrom ${ }^{1} \cdot$ Selamawit Woldesenbet ${ }^{1} \cdot$ Haimanote K. Bayabil $^{2} \cdot$ Monique Garcia $^{3} \cdot$ Ming Gao $^{1}$. \\ Peter Ampim ${ }^{1} \cdot$ Ripendra Awal $^{1} \cdot$ Ali Fares $^{1}$
}

Received: 9 August 2018 / Accepted: 4 December 2018 / Published online: 4 January 2019

(C) The Author(s) 2019

\begin{abstract}
Small-scale vegetable and fruit crop producers in the USA use locally available commercial organic fertilizers and soil amendments recycled from municipal and agricultural wastes. Organic soil amendments provide crops with their nutrient needs and maintain soil health by modifying its physical, chemical, and biological properties. However, organic soil amendments might add unwanted elements such as toxic heavy metals or salts, which might inhibit crop growth and reduce yield. Therefore, the objective of this study was to evaluate phytotoxicity of three commercial organic amendments, chicken manure, milorganite, and dairy manure, to collard greens using the seed germination bioassay and chemical analysis of the organic amendments. The seed germination bioassay was conducted by incubating collard greens seeds to germinate in 1:10 (w/v) organic amendment aqueous extracts. Results of this work identified phytotoxic effects of chicken manure and milorganite, but not dairy manure, to collard greens. Potentially phytotoxic chemicals such as copper, zinc, nickel, and salts were also higher in chicken manure and milorganite compared to dairy manure. In particular, nickel in chicken manure and milorganite aqueous extracts was 28 -fold and 21-fold, respectively, higher than previously reported toxic levels to wheat seedlings. The results demonstrate the need for more research on phytotoxicity of commercial organic soil amendments to ensure their safe use in vegetable and fruit crop production systems.
\end{abstract}

Keywords Agricultural waste $\cdot$ Municipal waste $\cdot$ Manure $\cdot$ Organic fertilizer $\cdot$ Phytotoxicity $\cdot$ Nickel $\cdot$ Germination $\cdot$ Collard greens

\section{Introduction}

Small-scale vegetable and fruit crop growers are transitioning from conventional farming to environmentally friendly and more profitable semi-organic or organic farming (Reganold and Wachter 2016); therefore, they are shifting from using

Responsible editor: Gangrong Shi

Ali Fares

alfares@pvamu.edu

1 Cooperative Agricultural Research Center, College of Agriculture and Human Sciences, Prairie View A\&M University, Prairie View, TX 77446, USA

2 Agricultural and Biological Engineering, Tropical Research and Education Center, Institute of Food and Agricultural Sciences, University of Florida, Homestead, FL 33031, USA

3 Department of Biology, College of Science and Arts, Prairie View A\&M University, Prairie View, TX 77446, USA conventional inorganic fertilizers to organic fertilizers and soil amendments prepared from municipal, industrial, and farm wastes (Wortman et al. 2017). Organic amendments are mixed with topsoil to improve the organic matter contents of agricultural soils and maintain soil health by modifying its physical, chemical, and biological properties (Eden et al. 2017; Ferreras et al. 2006). Organic fertilizers and soil amendments improve soil fertility, nutrient availability, soil aeration, and water holding capacity (Diacono and Montemurro 2010; Wortman et al. 2017). Interestingly, improvement in water holding capacity of soils treated with organic amendments increased the yield of maize and soybean under drought conditions (Lotter et al. 2003).

Unlike conventional inorganic fertilizers, the nutrient content and chemical composition of organic amendments prepared from agricultural and municipal solid wastes could vary depending on their origin and technologies used to convert these bioresources into organic fertilizers or soil amendments (Emino and Warman 2004; Tognetti et al. 2005). In addition, 
the level of nitrogen, the most limiting plant nutrient, in organic amendments is lower than in conventional inorganic fertilizers (Rigby and Smith 2014). Moreover, the nitrogen in organic fertilizers and soil amendments is slowly released to plants (Cogger et al. 2011). Therefore, to meet nitrogen requirements of crops, organic amendments are applied at higher rates (Cogger et al. 2011). Besides nitrogen, organic amendments contain plant macro- and micronutrients including phosphorus, potassium, copper, zinc, iron, and heavy metals, such as chromium, arsenic, selenium, nickel, and salts (Alvarenga et al. 2015). With higher rates of application, some of the nutrients, heavy metals or salts in organic fertilizers and soil amendments, could reach toxic levels, inhibit crop growth, and reduce yield. Therefore, determining phytotoxicity of organic soil amendments prior to their use in agricultural soils is critical for developing sustainable small-scale semiorganic or organic crop production practices that depend on bioresources recycled from municipal, industrial, and farm wastes.

In the USA, commercial organic fertilizers and soil amendments recycled from municipal and agricultural wastes are commonly used for growing small-scale vegetable and fruit crops and ornamental plants. It is also economically feasible to use commercial organic fertilizers and soil amendments as they are easily obtained from local stores (Araji et al. 2001). Furthermore, commercial organic fertilizers and soil amendments are ready for use and can be directly applied to agricultural soils without the need for further processing. However, their potential phytotoxic effects should be investigated in order to optimize their use in the production of horticultural crops and ornamental plants.

Phytotoxicity of organic soil amendments is evaluated using various chemical and biological approaches (Barral and Paradelo 2011; Luo et al. 2018). Potentially phytotoxic substances and their levels could be identified using expensive and laborious analytical chemistry methods. However, the sensitivity of plant species to phytotoxic chemicals in organic amendments may vary. Phytotoxicity of organic soil amendments could be also due to synergetic effects when the level of each of potentially toxic chemicals is lower than it can induce toxicity (Barral and Paradelo 2011; Emino and Warman 2004). Therefore, it may not be easy to identify phytotoxicity exclusively using analytical methods. In contrast, however, less expensive and quicker bioassays (e.g., seed germination test), in conjunction with chemical analysis, could be effective in determining phytotoxicity of organic soil amendments. Germination test can be conducted by incubating seeds in aqueous extracts of organic amendments or growing plants in organic amendments with or without mixing with soils (Barral and Paradelo 2011; Emino and Warman 2004; Luo et al. 2018). Such bioassays identified phytotoxicity of soil amendments prepared from plant residues, livestock farms, and biosolids from municipal and industrial wastes.
The seed germination bioassays were also used to monitor the stability and maturity of composts (Hase and Kawamura 2012; Tiquia 2010; Young et al. 2016). During composting, bacteria degrade the organic matter in the composted material. A compost is characterized as stable when it is relatively more resistant to further decomposition and mature when the phytotoxic compounds produced during the decomposition process such as ammonia disappear (Bernal et al. 2009; Komilis 2015). Stable and mature composts are applied to agricultural soils. However, heavy metals and salts from the original composted materials that are not eliminated during composting could be toxic to plants. Although commercial organic soil amendments could be stable and mature, they may contain phytotoxic substances from the original material that adversely affect crop growth and reduce yield. Therefore, we investigated the phytotoxicity of three commercial organic soil amendments commonly used in the USA (chicken manure, milorganite, and dairy manure) using a seed germination bioassay.

A widely used germination test protocol for identifying phytotoxicity is incubation of seeds to germinate in 1:10 ( $w /$ v) compost aqueous extracts (reviewed by Luo et al. 2018). Either monocot or eudicot seeds can be used for the germination test (Barral and Paradelo 2011; Luo et al. 2018). Therefore, we conducted seed germination bioassay by incubating collard greens (Brassica oleracea L. Acephala group) seeds in aqueous extracts of chicken manure, milorganite, and dairy manure. Furthermore, we analyzed the chemical properties and composition of the aqueous extracts. Our studies identified phytotoxicity of chicken manure and milorganite to collard greens possibly due to higher levels or synergetic effects of micronutrients, salts, and heavy metals.

\section{Materials and methods}

\section{Seed germination bioassay}

Phytotoxicity of commercial organic fertilizers and soil amendments was investigated in Petri dishes by incubating collard greens seeds with aqueous extracts of milorganite (Milorganite), granulated and dehydrated chicken manure (Medina), and composted dairy manure (Black Kow). Milorganite (Milwaukee Organic Nitrogen) is prepared from heat-dried microbes that digested municipal and industrial wastes from Milwaukee Metropolitan Sewerage District (MMSD) (Archer 2007). Milorganite can be used as a soil amendment and fertilizer for the production of diverse crops (Cogger et al. 2011). According to the label on the packaging materials, the nitrogen contents of milorganite, chicken manure, and cow manure is $6 \%, 3 \%$, and $0.5 \%$, respectively, which were validated in our lab by analyzing samples from these organic amendments using inductive coupled plasma 
optical emission spectrometer (Agilent ICP-5100) working with both radial and axial view and $\mathrm{C}, \mathrm{H}, \mathrm{N}$, and $\mathrm{S}$ content using elementar vario Macro tube.

To conduct seed germination bioassay, fresh aqueous extracts (1st extract) were prepared by shaking $1 \mathrm{~g}$ of milorganite, chicken manure, or dairy manure with $10 \mathrm{ml}$ of deionized water $(1: 10 \mathrm{w} / \mathrm{v})$ on a rotary shaker for $1 \mathrm{~h}$. The solutions were centrifuged at $5000 \mathrm{~g}$ for $15 \mathrm{~min}$, and then filtered through $0.8-\mu \mathrm{m}$ membrane filter. A range of dilutions of the aqueous extracts using deionized water as diluent was prepared. Commercial collard greens seed variety Tiger (F1) was obtained from a seed company (Johnny's Selected Seeds). Ten collard greens seeds were set to germinate on Whatman filter paper wetted with $4 \mathrm{ml}$ aqueous extracts or deionized water (control) in 100-mm-diameter and 25-mm-height Petri dishes (Fisher Scientific) incubated at $25^{\circ} \mathrm{C}$. After 3 days, the number of germinated seeds and the radicle length of each germinated seed were documented. A seed with a radicle length of at least $2 \mathrm{~mm}$ was considered as germinated. A second round of aqueous extracts (2nd extract) were prepared by adding $10 \mathrm{ml}$ deionized water to the residues from the first aqueous extract preparations (1st extract), incubated for $1 \mathrm{~h}$ on a rotary shaker, centrifuged at $5000 \mathrm{~g}$ for $15 \mathrm{~min}$, and then filtered through $0.8-\mu \mathrm{m}$ membrane filter. Germination tests were conducted by incubating ten collard greens seeds with a range of dilutions of the second aqueous extracts. After 3 days, the number of germinated seeds with radicle length at least $2 \mathrm{~mm}$ and the radicle length of each germinated seed were documented. The whole experiment including preparation of fresh aqueous extracts and germination test was repeated four times, and the results were analyzed by determining the relative seed germination (RSG), relative radicle growth (RRG), and germination index (GI) as shown below:

$$
\begin{aligned}
\mathrm{RSG}= & \frac{\text { Number of germinated seeds in aqueous extract }}{\text { Number of germinated seeds in deionized water (control) }} \\
& \times 100 \%
\end{aligned}
$$$$
\begin{aligned}
\mathrm{RRG}= & \frac{\text { Radicle length of germinated seeds in aqueous extracts }}{\text { Radicle length of germinated seeds in deionized water (control) }} \\
& \times 100 \%
\end{aligned}
$$

$G \mathrm{I}=\mathrm{RSG} \times \mathrm{RRG} \times 100 \%$

\section{Chemical analysis of organic fertilizers and soil amendments}

The chemical properties and composition of the first and second aqueous extracts of chicken manure, milorganite, and dairy manure were analyzed using $\mathrm{pH}$ meter (accumet AB15), electrical conductivity (EC) meter (Milwaukee MW 802), and an ICP-OES. Heavy metals and plant macro- and micronutrients analyzed include arsenic (As), chromium $(\mathrm{Cr})$, cadmium $(\mathrm{Cd})$, mercury $(\mathrm{Hg})$, copper $(\mathrm{Cu})$, nickel $(\mathrm{Ni})$, lead $(\mathrm{Pb})$, selenium $(\mathrm{Se})$, zinc $(\mathrm{Zn})$, boron $(\mathrm{B})$, iron $(\mathrm{Fe})$, sodium $(\mathrm{Na})$, and phosphorus (P). Calibration standards for the ICPOES analysis were prepared from single elements $(\mathrm{P}, \mathrm{Na}, \mathrm{Fe}$, and B) (Sigma) and pre-mixed elements (As, $\mathrm{Cd}, \mathrm{Cr}, \mathrm{Cu}, \mathrm{Mn}$, $\mathrm{Ni}, \mathrm{Hg}, \mathrm{Pb}, \mathrm{Se}$, and $\mathrm{Zn}$ ) (Agilent) diluted with $1 \% \mathrm{HNO}_{3}$. All reagents were analytical grade or better. The analysis was conducted on three independently prepared first and second aqueous extracts of chicken manure, milorganite, and dairy manure as described above.

\section{Effect of sodium salt on the germination and radicle growth of collard greens seeds}

The effect of sodium salts on the germination and radicle growth of collard greens seeds was investigated using sodium chloride $(\mathrm{NaCl})$ solution. A $20,000 \mathrm{ppm} \mathrm{Na}^{+}$stock solution was prepared by dissolving $2.54 \mathrm{~g} \mathrm{NaCl}$ in $50 \mathrm{ml}$ deionized water. The amount of $\mathrm{Na}^{+}$in the stock solution was confirmed using ICP-OES. A range of $\mathrm{NaCl}$ dilutions were prepared from the stock solution containing from 50 to $10,000 \mathrm{ppm}$ $\mathrm{Na}^{+}$in deionized water to a final volume of $4 \mathrm{ml}$ and used in germination test in Petri dishes using the same method as described for the aqueous extracts of chicken manure, milorganite, and dairy manure.

\section{Statistical analysis}

The number of germinated seeds and the average radicle length in each of the four biological replicates were determined. The RSG, RRG, and GI of each biological replicate were calculated using the equations shown in the "Seed germination bioassay" section of the materials and methods. The results reported in this paper are mean GI, RSG, and RRG of the four biological replicates, and the error bars are standard error of the mean (SE) calculated using the equation $\mathrm{SE}=\mathrm{SD} /$ $\sqrt{ } N$, where SD is standard deviation of the means, and $N$ is the number of biological replicates. The physical properties and chemical analysis results reported in this paper were also analyzed similarly.

\section{Results}

\section{Germination of collard greens in chicken manure, milorganite, and dairy manure aqueous extracts}

The seed germination bioassay identified potential phytotoxic effects of chicken manure and milorganite, but not dairy 
manure, to collard greens. As shown in Fig. 1, the germination index (GI) in $100 \%$ chicken manure and milorganite first aqueous extracts was $1.9 \%$ and $0 \%$, respectively. The results indicate strong phytotoxicity of chicken manure and milorganite to collard greens. We hypothesized that the observed phytotoxicity could be due to soluble substances in the original material or phytotoxic by-products during the conversion of poultry farm and municipal wastes into chicken manure and milorganite, respectively, that could be washed away in the first extract. Therefore, we conducted germination test by incubating collard greens seeds in an aqueous extract (2nd extract) prepared by adding $10 \mathrm{ml}$ of deionized water to residue from the first aqueous extract preparations. The GI in $100 \%$ chicken manure and milorganite second aqueous extracts was $2.6 \%$ and $14.3 \%$, respectively (Fig. 1a and b). The results indicate the phytotoxic substances in chicken manure and milorganite might not be easily removed by leaching. The GI at $12.5 \%$ dilution in the first extract of chicken manure was not different from the control and significantly reduced in $25 \%$ aqueous extract compared to control (Fig. 1a). The results indicate the phytotoxic substances act in a concentration dependent manner. The GI in milorganite at $12.5 \%$ dilution was about $40.5 \%$ indicating phytotoxic effects of milorganite

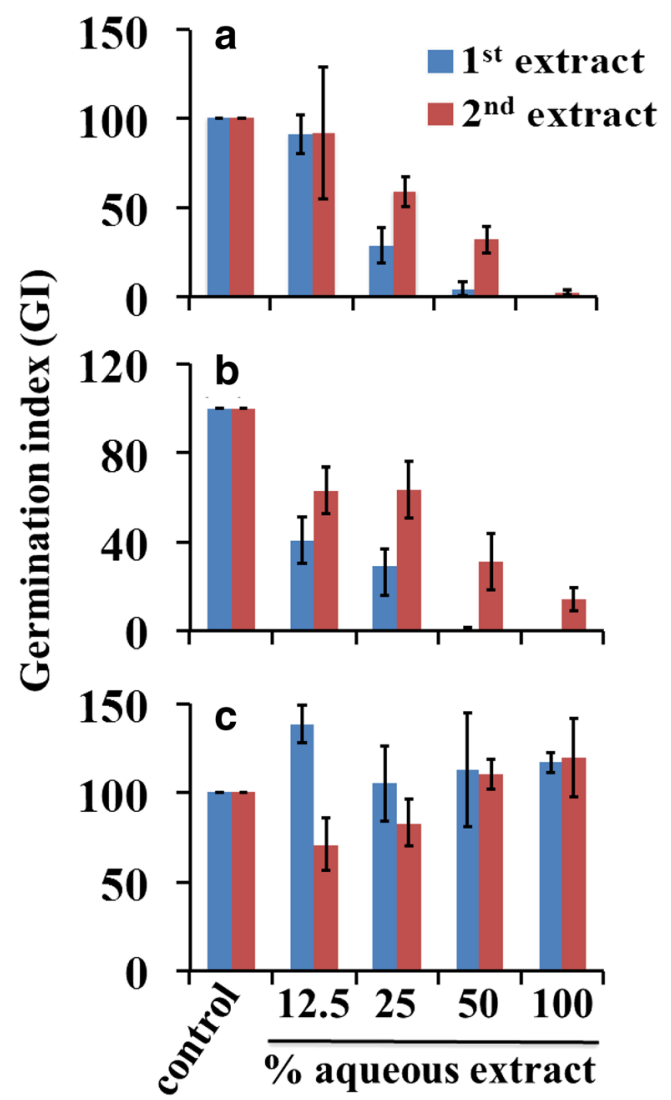

Fig. 1 Germinated index of collard greens seeds germinated in aqueous extracts of chicken manure (a), milorganite (b), and dairy manure (c). GI was calculated from four independent experiments. Data are mean $\pm \mathrm{SE}$, $N=4$ even at low dilution rates (Fig. 1b). Dairy manure appears to be free of phytotoxic effects (Fig. 1c). In fact, at $12.5 \%$ dilution, the GI in the first extract was $139 \%$ of the control indicating a stimulating effect of dairy manure at lower application rates (Fig. 1c). Interestingly, the GI at $12.5 \%$ dilution in the second extract of dairy manure was $71 \%$ of the control indicating mild phytotoxic effect. The GI in the $25 \%$ dilution was reduced from $105 \%$ of the control in the first extract to $83 \%$ of the control in the second extract. However, there was no difference in the GI between the first extract and the second extract when the seeds were incubated to germinate in $50 \%$ and $100 \%$ aqueous extracts. It appears that at lower dilution rates in the second extract, the stimulating effect of dairy manure disappeared resulting in mild phytotoxicity.

In addition to GI, we analyzed the relative seed germination (RSG) and relative radicle growth (RRG) to see the effect of chicken manure, milorganite, and dairy manure aqueous extracts specifically on seed germination and root growth of collard greens. Both RSG and RRG were improved in 100\% chicken manure and milorganite second aqueous extracts compared to the level in the first aqueous extracts, with more improvement in RSG than RRG (Fig. 2). The RSG in dairy manure first and second aqueous extracts in all dilutions were similar and comparable to the RSG in the control (Fig. 2e). The RRG in $25 \%, 50 \%$, and $100 \%$ dairy manure first and second aqueous extracts were also comparable to the RRG in the control. Whereas the RRG in $12.5 \%$ dairy manure first aqueous extract was higher than the RRG in second aqueous extract and also in the control (Fig. 2f). Therefore, the stimulation of GI in $12.5 \%$ dairy manure first aqueous extract (Fig.1) was exclusively due to an increase in RRG.

\section{Chemical properties and composition of aqueous extracts of chicken manure, milorganite, and dairy manure}

To identify phytotoxic factors in chicken manure and milorganite, we analyzed the chemical properties and composition of the aqueous extracts used in the seed germination bioassay. As shown in Table 1, the $\mathrm{pH}$ in both chicken manure and dairy manure was comparable and alkaline, and slightly increased in the second extract compared to the first extract. However, seed germination and radicle growth were inhibited in chicken manure aqueous extracts, but not in dairy manure aqueous extracts. The $\mathrm{pH}$ of milorganite aqueous extracts was 6.2 and 6.7 in the first extract and second extract, respectively. Differential response of collard greens seed germination under similar $\mathrm{pH}$ as in chicken manure and dairy manure and an increase in GI in milorganite from the first extract $(0 \%)$ to the second extract (14\%) with little change in $\mathrm{pH}$ indicate phytotoxicity of chicken manure and milorganite is not related to their $\mathrm{pH}$. 
Fig. 2 Relative seed germination (RSG) and relative radicle (root) growth (RRG) of collard greens in aqueous extracts of chicken manure (a and $\mathbf{b})$, milorganite (c and $\mathbf{d}$ ), and dairy manure (e and f). Data are mean $\pm \mathrm{SE}, N=4$

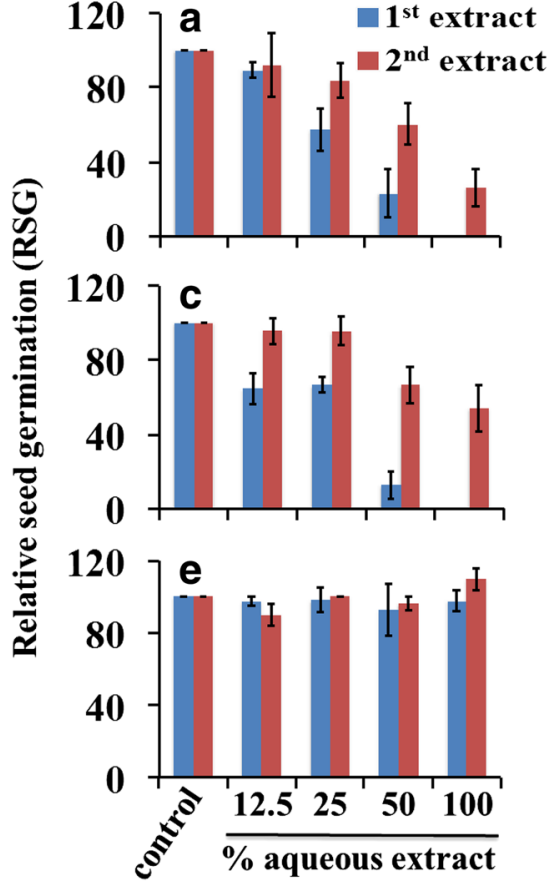

Electrical conductivity measurements are used to determine the level of salts in soil (He et al. 2012). A higher electrical conductivity indicates higher level of salts in a solution (Visconti et al. 2010). The electrical conductivity of the first extract of chicken manure was $8.1 \mathrm{mS} / \mathrm{cm}$ and decreased to $2.9 \mathrm{mS} / \mathrm{cm}$ in the second aqueous extract (Table 1). In milorganite, the EC in the first extract was about $2.3 \mathrm{mS} / \mathrm{cm}$ and reduced to about $0.6 \mathrm{mS} / \mathrm{cm}$ in the second extract, and in dairy manure, the $\mathrm{EC}$ was reduced from $0.4 \mathrm{mS} / \mathrm{cm}$ in the first extract to $0.1 \mathrm{mS} / \mathrm{cm}$ in the second extract. Although the EC in the second aqueous extracts of chicken manure and milorganite was reduced significantly, the GI in $100 \%$ aqueous extracts improved only slightly (Fig. 1).

Chemical analysis of the aqueous extracts of chicken manure, milorganite, and dairy manure might help identify potentially phytotoxic compounds. In general, the levels of most of the elements analyzed were higher in aqueous extracts of chicken manure followed by milorganite, while dairy manure had the lowest (Fig. 3). The average sodium ion $\left(\mathrm{Na}^{+}\right)$content of the first aqueous extracts of chicken manure, milorganite,

Table 1 Electrical conductivity (EC) and $\mathrm{pH}$ of the first and second aqueous extracts of chicken manure, milorganite, and dairy manure. Data are mean $\pm \mathrm{SD} ; N=3$ independently prepared aqueous extracts

\begin{tabular}{llllll}
\hline & $\mathrm{pH}$ & & \multicolumn{2}{c}{$\mathrm{EC}(\mathrm{mS} / \mathrm{cm})$} \\
\cline { 2 - 3 } \cline { 5 - 6 } \cline { 5 - 6 } & 1st extract & 2nd extract & & 1st extract & 2nd extract \\
\hline Chicken manure & $8.0 \pm 0.09$ & $8.3 \pm 0.51$ & & $8.1 \pm 0.14$ & $2.9 \pm 0.12$ \\
Milorganite & $6.2 \pm 0.04$ & $6.7 \pm 0.16$ & & $2.1 \pm 0.06$ & $0.6 \pm 0.02$ \\
Dairy manure & $8.4 \pm 0.19$ & $8.8 \pm 0.36$ & & $0.4 \pm 0.01$ & $0.1 \pm 0.01$ \\
\hline
\end{tabular}

and dairy manure was 442.2 parts per million (ppm), $63 \mathrm{ppm}$, and $36.3 \mathrm{ppm}$, respectively (Fig. 3). The level of $\mathrm{Na}^{+}$in the second aqueous extracts of chicken manure, milorganite, and dairy manure was $129.2 \mathrm{ppm}, 17.2 \mathrm{ppm}$, and $10.2 \mathrm{ppm}$, respectively. The level of $\mathrm{Na}^{+}$in the aqueous extracts was consistent with their EC values, highest in chicken manure and lowest in dairy manure (Table 1). The reduction in $\mathrm{Na}^{+}$from the first extract to the second extract (Fig. 3a and b) was also consistent with similar patterns of reduction in EC (Table 1). However, as with EC, although the level of $\mathrm{Na}^{+}$in the chicken manure was reduced from the first to the second extract, the GI in $100 \%$ in the second extract improved only slightly.

Plant micronutrients such as copper $(\mathrm{Cu})$, zinc $(\mathrm{Zn})$, and iron $(\mathrm{Fe})$ were relatively higher in chicken manure than in milorganite and dairy manure aqueous extracts (Fig. 3). Fe was higher in chicken manure followed by dairy manure and milorganite. It is unlikely that the low GI in $100 \%$ chicken manure first aqueous extract is due to Fe because the higher level of $\mathrm{Fe}$ in dairy manure compared to the level in milorganite did not affect seed germination and root growth of collard greens. The amount of $\mathrm{Cu}, \mathrm{Zn}$, and B was relatively higher in chicken manure. The amount of heavy metals and micronutrients was significantly reduced in the second aqueous extracts (Fig. 3b, d, and f). As shown in Table 2, the percentage reduction ranged from about $25 \%$ for $\mathrm{Cr}$ in chicken manure to more than $70 \%$ for $\mathrm{Cu}, \mathrm{Zn}$, and $\mathrm{Na}$. The patterns of reduction in milorganite were similar to those in chicken manure. Interestingly, while the level of Fe in chicken manure was reduced from $13.9 \mathrm{ppm}$ in the first extract to $5.7 \mathrm{ppm}$ in the second extract, the level of $\mathrm{Fe}$ in dairy manure was reduced from $6.0 \mathrm{ppm}$ in the first extract to $4.6 \mathrm{ppm}$ in the second 

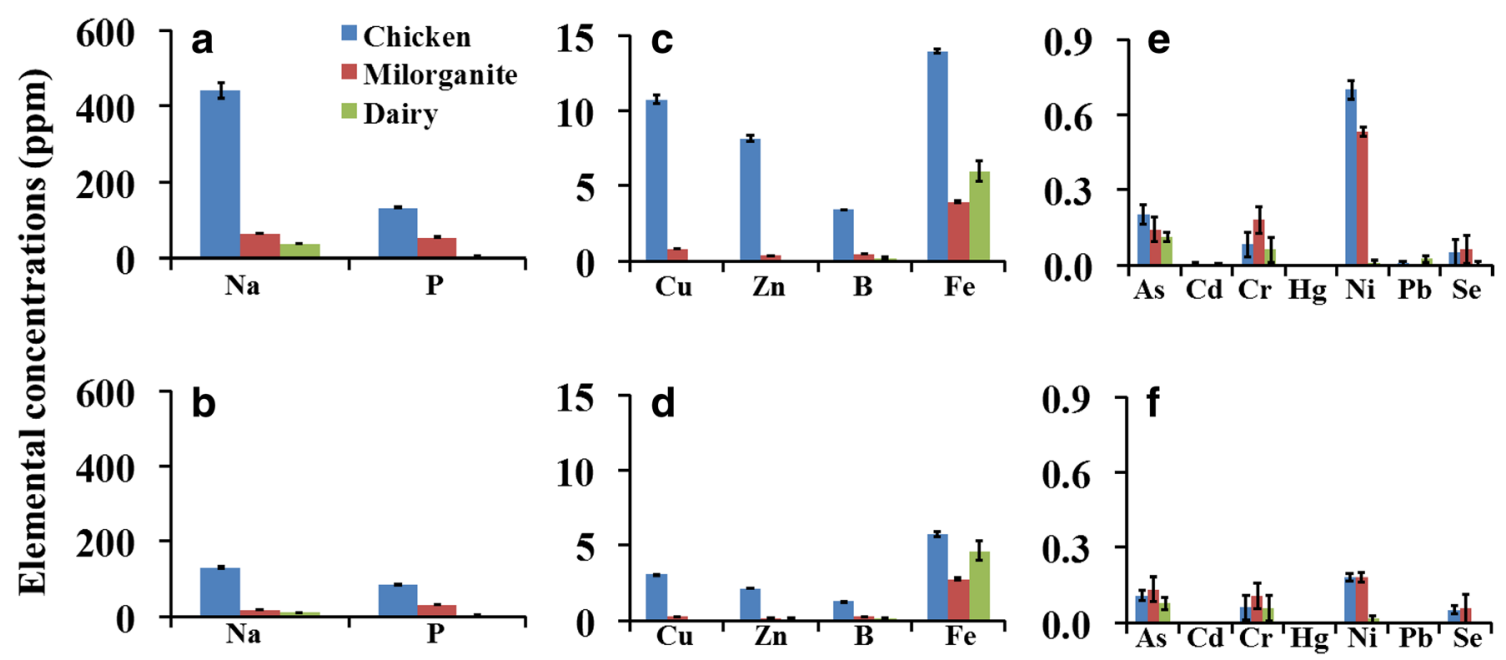

Fig. 3 Elemental composition in the first aqueous extracts (upper panel: a, c, e) and second aqueous extracts (lower panel: b, d, f) of chicken manure, milorganite, and dairy manure. Data are means $\pm \mathrm{SE}, N=3$ independently prepared aqueous extracts

extract. Potentially toxic heavy metals including arsenic (As), chromium $(\mathrm{Cr})$, and nickel $(\mathrm{Ni})$ were present in chicken manure and milorganite aqueous extracts (Fig. 3e). The higher level of $\mathrm{Ni}$ in chicken manure and milorganite aqueous extracts compared to dairy manure suggests that the phytotoxic effect could be due to Ni. The low level or below the detection level of heavy metals such as $\mathrm{Hg}$ and $\mathrm{Pb}$ in the organic amendments could be due to regulation on the use and disposal of such hazardous substances in agricultural and municipal wastes (Jain et al. 2005). Elements such as $\mathrm{Cd}$ and $\mathrm{Pb}$, which were already very low in the first aqueous extract of chicken manure, reduced by about $100 \%$ or they were below the detection limit in the second extract.

Table 2 Percentage reduction or increase (indicated by asterisks) of heavy metals, plant macro- and micronutrients in the second aqueous extracts of chicken manure, milorganite, and dairy manure compared to the first aqueous extracts

\begin{tabular}{lccc}
\hline Elements & Chicken manure & Milorganite & Dairy manure \\
\hline $\mathrm{Na}$ & 70.8 & 72.6 & 71.9 \\
$\mathrm{P}$ & 36.2 & 43.0 & 29.4 \\
$\mathrm{Cu}$ & 71.6 & 66.7 & 0.0 \\
$\mathrm{Zn}$ & 73.7 & 60.6 & $92.5^{*}$ \\
$\mathrm{~B}$ & 63.1 & 32.5 & 10.6 \\
$\mathrm{Fe}$ & 58.9 & 29.4 & 22.4 \\
$\mathrm{As}$ & 46.3 & 4.8 & 31.3 \\
$\mathrm{Cd}$ & 100.0 & 0.0 & 100.0 \\
$\mathrm{Cr}$ & 25.0 & 39.6 & 5.6 \\
$\mathrm{Hg}$ & 0.0 & 0.0 & 0.0 \\
$\mathrm{Ni}$ & 74.3 & 65.9 & $25.0^{*}$ \\
$\mathrm{~Pb}$ & 100.0 & 0.0 & 100.0 \\
$\mathrm{Se}$ & 0.0 & 8.1 & 100.0 \\
\hline
\end{tabular}

\section{Effect of sodium salts on the germination of collard greens seeds}

Seed germination and seedling growth are inhibited in soils with high salts (Hakim et al. 2010; Hanin et al. 2016; Ibrahim 2016). It is possible that the high level of salts in chicken manure indicated by higher EC $(8.1 \mathrm{mS} / \mathrm{cm})$ and $\mathrm{Na}^{+}$ (442.2 ppm and $129.2 \mathrm{ppm}$ in the 1st and 2nd aqueous extracts, respectively) could result in the inhibition of seed germination and radicle growth (Table 1, Fig. 3a). Therefore, we conducted germination test in a series of sodium chloride $(\mathrm{NaCl})$ solutions containing from 50 to $10,000 \mathrm{ppm} \mathrm{Na}^{+}$to determine the sensitivity of collard greens seed germination to sodic salts. The germination and radicle growth of collard greens seeds incubated in $\mathrm{NaCl}$ containing 50 to $1000 \mathrm{Na}^{+}$ were not different from the control (Fig. 4). The effect of $\mathrm{NaCl}$ on seed germination was observed at $5000 \mathrm{Na}^{+} \mathrm{ppm}$, in particular the radicle growth was suppressed. The germination of collard greens seeds was inhibited at $10,000 \mathrm{Na}^{+} \mathrm{ppm}$.

\section{Discussion}

Commercial soil amendments prepared by composting industrial, municipal, and agricultural wastes using appropriate technologies could be alternative sources of organic fertilizers by organic or semi-organic crop growers. Regulations for organic soil amendments recycled from municipal and agricultural wastes are developed with a focus on potential hazards to human health and the environment while largely ignoring quality of organic amendments as a fertilizers and their toxicity to crop plants (Cesaro et al. 2015; Rigby et al. 2016). Therefore, phytotoxicity of commercial organic fertilizers and soil amendments should be investigated prior applying to agricultural soils to reduce risk to crops. In this study, we 


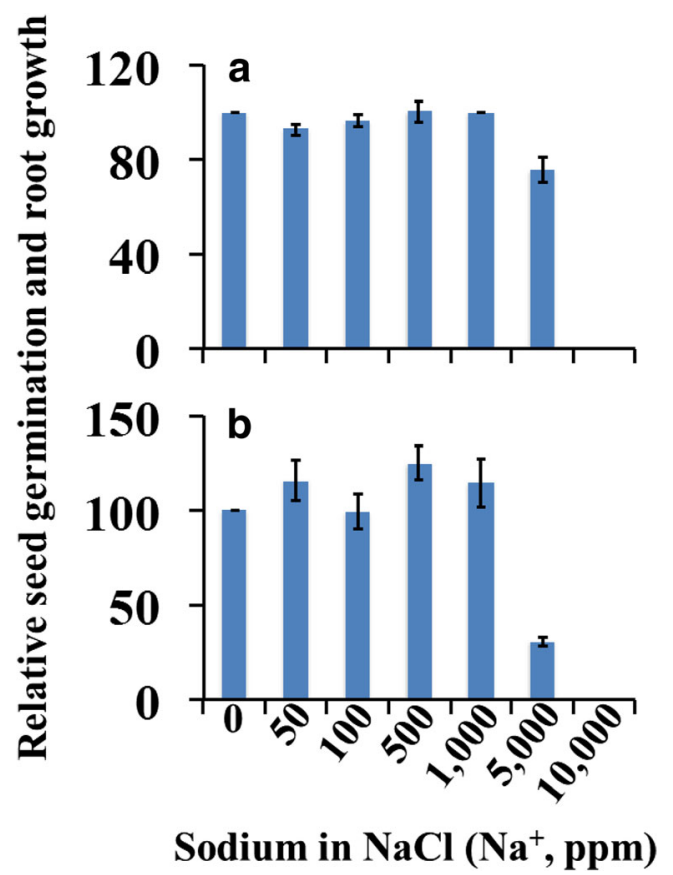

Fig. 4 Relative seed germination (a) and relative radicle (root) growth (b) of collard greens seeds in sodium chloride solution. Data are mean $\pm \mathrm{SE}$, $N=3$

investigated phytotoxicity of three commercial organic fertilizers and soil amendments commonly used in the USA (chicken manure, milorganite, and dairy manure), using the seed germination bioassay and analyzing chemical properties and composition of their aqueous extracts.

Germination index (GI) is commonly used to determine phytotoxicity of compost (Luo et al. 2018). A GI greater than $80 \%$ indicates that the compost is free of phytotoxicity, whereas a GI below $80 \%$ indicates potential phytotoxicity of compost to crops and a GI below 50\% indicates high phytotoxicity (Barral and Paradelo 2011). The GI of collard greens seeds incubated in $100 \%$ aqueous extracts of chicken manure and milorganite was close to zero indicating strong phytotoxicity of these organic amendments. The GI at 25\% dilution of aqueous extracts of chicken manure and milorganite was less than $80 \%$. The results confirm the strong phytotoxicity of these two organic amendments to collard greens and possibly to other crops. Leaching the soil with irrigation water or after natural rainfall after application of organic amendments containing water-soluble toxic chemicals may reduce salinity and phytotoxicity (Kuepper 2003). It is also possible that some of the composting by-products such as organic acids could be washed away following irrigation or natural rainfall. To explore if this is possible with chicken manure and milorganite, we investigated the effect of second aqueous extracts, prepared by adding deionized water to the residues from the first aqueous extract preparations, on the germination of collard greens seeds. The GI in $100 \%$ of the second extract was slightly improved, but it was still below 50\% (Fig. 1). Our results suggest that the phytotoxic chemicals in chicken manure and milorganite are slowly released into the solution and might not be easily removed by leaching of the soil during irrigation operations following their application.

The phytotoxicity of an organic amendment could be due to its effect on seed germination or root growth or both (Emino and Warman 2004; Tiquia et al. 1996). Understanding the contribution of each is important in developing strategies to reduce or eliminate the effect of organic amendments on seedling establishment. For example, if the phytotoxic effect is on germination and subsequent growth is not affected, seeds could be germinated in growth media in nurseries without adding organic amendments, and then, the seedlings can be transplanted to fields with soils amended with organic fertilizers. Analysis of the seed germination and root growth results indicate that the phytotoxic effects of chicken manure and milorganite were on both seed germination and root growth. However, root growth was more inhibited than seed germination. In fact, at $25 \%$ milorganite second aqueous extract, the seed germination was not affected while root growth was inhibited (Fig. 2c and d).

Dairy manure aqueous extracts did not affect the seed germination or root growth of collard greens indicating dairy manure could be free of toxic chemicals. Interestingly, when the seeds were incubated with $12.5 \%$ aqueous extracts of dairy manure, the GI was $139 \%$ of the control specifically due to enhanced growth of the radicle. The high GI indicates the stimulating effect of chemicals present in the dairy manure aqueous extracts (Moldes et al. 2007). However, this stimulatory effect of dairy manure was not only absent in the second extract but also the GI was less than $80 \%$. In the second extract of dairy manure, either the stimulant was reduced or the inhibitor was increased or both. The results suggest that the balance between growth stimulants and inhibitors in the organic amendments could determine seed germination and seedling development. Therefore, identifying chemicals in organic amendments that stimulate or inhibit seed germination could help to develop ways to improve the usefulness of recycled organic amendments in agriculture. Furthermore organic amendments that do not have phytotoxic effect on seed germination can have an effect at later stages of plant growth when the amount of inhibitors released from the organic amendments increase. Therefore, while our results indicate that dairy manure might not be phytotoxic to collard greens and other crops, additional studies are needed to make conclusions. For example, increasing incubation and shaking time during the preparation of the aqueous extracts from $1 \mathrm{~h}$ used in the current experiment to 24 or $48 \mathrm{~h}$ or longer might be useful to confirm if dairy manure does not contain potentially phytotoxic chemicals.

Seed germination and seedling growth are sensitive to soil salinity (Bajji et al. 2002; Hakim et al. 2010; Houle et al. 2001). The sodium-ion level in chicken manure was higher 
than in milorganite or dairy manure, but collard greens seeds germinated at much higher levels of $\mathrm{Na}^{+}$. In addition, the level of sodium in chicken manure was significantly reduced from the first extract to the second extract, but phytotoxicity was only slightly reduced. It is possible that while salts in the organic amendments can contribute to their phytotoxic effects, the phytotoxicity in chicken manure and milorganite might not be exclusively due to salts as significant reduction in EC and salt from the first to the second extract did not significantly reduce or eliminate phytotoxicity.

Potentially toxic micronutrients and heavy metals identified in chicken manure and milorganite include $\mathrm{Cu}, \mathrm{Zn}, \mathrm{Ni}$, $\mathrm{As}$, and $\mathrm{Cr}$. The high level of $\mathrm{Cu}$ and $\mathrm{Zn}$ in chicken manure might be due to the use of these two metals in poultry diet to protect chickens from disease and improve productivity (Bolan et al. 2010; Yazdankhah et al. 2014). Paradelo et al. (2010) identified phytotoxic effects of $10 \mathrm{mg} / \mathrm{L} \mathrm{Cu}$ solution, which is equivalent to $10 \mathrm{ppm}$, on the germination of cress and barley. In the current study, the level of $\mathrm{Cu}$ in the first aqueous extracts of chicken manure was 10.8 ppm, which is comparable to the level of $\mathrm{Cu}$ that induced phytotoxicity in cress and barley seeds. However, the reduction in the level of $\mathrm{Cu}$ to $3.1 \mathrm{ppm}$ in the second aqueous extract of chicken manure was not associated with elimination of phytotoxicity. The level of $\mathrm{Zn}$ phytotoxic to cress and barley was higher than $50 \mathrm{mg} /$ L (Paradelo et al. 2010), which is sixfold higher than the level in chicken manure aqueous extracts in the current study. Therefore, it is unlikely that phytotoxicity of chicken manure could be due to $\mathrm{Cu}$ or $\mathrm{Zn}$.

$\mathrm{Ni}$ is a micronutrient essential for plant growth at very low concentration, but could be toxic to germinating seeds when present at higher level (Seregin and Kozhevnikova 2006). As low as $25-\mu \mathrm{g} / \mathrm{L}$ nickel, which is equivalent to $0.025 \mathrm{ppm}$, in a hydroponic nutrient solution reduced the growth of wheat seedlings (Parlak 2016). The level of $\mathrm{Ni}$ in the first aqueous extracts of chicken manure and milorganite was 0.7 ppm (28fold) and $0.53 \mathrm{ppm}$ (21-fold), respectively, higher than the level of $\mathrm{Ni}$ phytotoxic to wheat seedlings as reported by Parlak (2016). Therefore, phytotoxicity of chicken manure and milorganite could be due to Ni. Interestingly, a combination of $\mathrm{Ni}$ and $\mathrm{NaCl}$ was more toxic to Indian mustard (Brassica juncea) growth than either $\mathrm{Ni}$ or $\mathrm{NaCl}$ on its own (Yusuf et al. 2012). Therefore, the strong phytotoxicity of chicken manure and milorganite may not be exclusively due to $\mathrm{Ni}$; it can be also due to synergetic effect of $\mathrm{Ni}$ and several other heavy metals and salts (Barral and Paradelo 2011; Emino and Warman 2004). It is also possible that other chemicals that were not analyzed in this study could potentially be responsible for the phytotoxic effects of milorganite and chicken manure. The impact of such chemicals is likely to be even more with milorganite due to the fact that it is prepared from heat-dried microbes that digested municipal wastes (Archer 2007), and thus, organic by-products such as phenols and organic acid could be responsible for its phytotoxic effects.

\section{Conclusion}

Commercial scale conversion of municipal and agricultural wastes into organic soil amendments provides solutions to the growing demand of semi-organic or organic farmers for organic soil amendments and appropriate management of pollutions. Commercial organic fertilizers and soil amendments might pose little concern for human health and the environment. However, using widely accepted method for determining phytotoxicity of compost to crops, we identified strong phytotoxicity of commercial chicken manure and milorganite to collard greens. We also identified a higher level of potentially phytotoxic chemicals such as $\mathrm{Ni}$ and sodic salts in the aqueous extracts of chicken manure and milorganite. It is possible that there may be additional phytotoxic chemicals that this study did not address. In addition, there is variation in the degree of tolerance of crops species to phytotoxic levels of micronutrients, salts, and heavy metals. Therefore, further studies of phytotoxicity of commercial organic fertilizers and soil amendments are needed for developing strategies for their safe use in semi-organic or organic vegetable and fruit crop production systems.

Acknowledgments We would like to thank Robert Douglas, Leona Edegbe, Asja Jackson, and Kedist Teshome for their help with the experiments. The United States Department of Agriculture-National Institute of Food and Agriculture (USDA-NIFA) Evans-Allen funds at Prairie View A\&M University supported this work.

Open Access This article is distributed under the terms of the Creative Commons Attribution 4.0 International License (http:// creativecommons.org/licenses/by/4.0/), which permits unrestricted use, distribution, and reproduction in any medium, provided you give appropriate credit to the original author(s) and the source, provide a link to the Creative Commons license, and indicate if changes were made.

Publisher's Note Springer Nature remains neutral with regard to jurisdictional claims in published maps and institutional affiliations.

\section{References}

Alvarenga P, Mourinha C, Farto M, Santos T, Palma P, Sengo J, Morais MC, Cunha-Queda C (2015) Sewage sludge, compost and other representative organic wastes as agricultural soil amendments: benefits versus limiting factors. Waste Manag 40:44-52

Araji AA, Abdo ZO, Joyce P (2001) Efficient use of animal manure on cropland - economic analysis. Bioresour Technol 79:179-191

Archer MJ (2007) Marketing biosolids: the experience of milorganite with special reference to Canada. In: Waste water biosolids sustainability: technical, managerial, and public synergy, Moncton, New Brunswick, Canada. pp 1017-1019. http://citeseerx.ist.psu.edu/ viewdoc/download?doi=10.1.1.847.9238\&rep=rep1\&type=pdf 
Bajji M, Kinet JM, Lutts S (2002) Osmotic and ionic effects of $\mathrm{NaCl}$ on germination, early seedling growth, and ion content of Atriplex halimus (Chenopodiaceae). Can J Bot 80:297-304

Barral MT, Paradelo R (2011) A review on the use of phytotoxicity as a compost quality indicator. Dyn Soil Dyn Plant 5:36-44

Bernal MP, Alburquerque JA, Moral R (2009) Composting of animal manures and chemical criteria for compost maturity assessment. A review. Bioresour Technol 100:5444-5453

Bolan NS, Szogi AA, Chuasavathi T, Seshadri B, Rothrock MJ, Panneerselvam P (2010) Uses and management of poultry litter. World Poult Sci J 66:673-698

Cesaro A, Belgiorno V, Guida M (2015) Compost from organic solid waste: quality assessment and European regulations for its sustainable use. Resour Conserv Recy 94:72-79

Cogger CG, Bary AI, Myhre EA (2011) Estimating nitrogen availability of heat-dried biosolids. Appl Environ Soil Sci 2011:1-7. https://doi. org/10.1155/2011/190731

Diacono M, Montemurro F (2010) Long-term effects of organic amendments on soil fertility: a review. Agron Sustain Dev 30:401-422

Eden M, Gerke HH, Houot S (2017) Organic waste recycling in agriculture and related effects on soil water retention and plant available water: a review. Agron Sustain Dev 37(11):37. https://doi.org/10. 1007/s13593-13017-10419-13599

Emino ER, Warman PR (2004) Biological assay for compost quality. Compost Sci Util 12:342-348

Ferreras L, Gomez E, Toresani S, Firpo I, Rotondo R (2006) Effect of organic amendments on some physical, chemical and biological properties in a horticultural soil. Bioresour Technol 97:635-640

Hakim MA, Juraimi AS, Begum M, Hanafi MM, Ismail MR, Selamat A (2010) Effect of salt stress on germination and early seedling growth of rice (Oryza sativa L.). Afr J Biotechnol 9:1911-1918

Hanin M, Ebel C, Ngom M, Laplaze L, Masmoudi K (2016) New insights on plant salt tolerance mechanisms and their potential use for breeding. Front Plant Sci 7:1787. https://doi.org/10.3389/fpls.2016. 01787

Hase T, Kawamura K (2012) Germination test on Komatsuna (Brassica rapa var. peruviridis) seed using water extract from compost for evaluating compost maturity: evaluating criteria for germination and effects of cultivars on germination rate. J Mater Cycles Waste Manage 14:334-340

He YB, DeSutter T, Prunty L, Hopkins D, Jia XH, Wysocki DA (2012) Evaluation of 1:5 soil to water extract electrical conductivity methods. Geoderma 185:12-17

Houle G, Morel L, Reynolds CE, Siegel J (2001) The effect of salinity on different developmental stages of an endemic annual plant, Aster laurentianus (Asteraceae). Am J Bot 88:62-67

Ibrahim EA (2016) Seed priming to alleviate salinity stress in germinating seeds. J Plant Physiol 192:38-46

Jain P, Kim H, Townsend TG (2005) Heavy metal content in soil reclaimed from a municipal solid waste landfill. Waste Manag 25: $25-35$

Komilis DP (2015) Compost quality: is research still needed to assess it or do we have enough knowledge? Waste Manag 38:1-2. https://doi. org/10.1016/j.wasman.2015.01.023

Kuepper G (2003) Manures for organic crop production. ATTRA publication WWW.attra.ncat.org
Lotter DW, Seidel R, Liebhardt W (2003) The performance of organic and conventional cropping systems in an extreme climate year. Am J Altern Agric 18:146-154

Luo Y, Liang J, Zeng GM, Chen M, Mo D, Li GX, Zhang DF (2018) Seed germination test for toxicity evaluation of compost: its roles, problems and prospects. Waste Manag 71:109-114

Moldes AB, Vazquez M, Dominguez JM, Diaz-Fierros F, Barral MT (2007) Evaluation of mesophilic biodegraded grape marc as soil fertilizer. Appl Biochem Biotechnol 141:27-36

Paradelo R, Villada A, González D, Barral MT (2010) Evaluation of the toxicity of heavy metals and organic compounds in compost by means of two germination-elongation tests. Fresenius Environ Bull 19:956-962

Parlak KU (2016) Effect of nickel on growth and biochemical characteristics of wheat (Triticum aestivum L.) seedlings. Njas-Wagen J Life Sc 76:1-5

Reganold JP, Wachter JM (2016) Organic agriculture in the twenty-first century. Nat Plants 2:15221. https://doi.org/10.1038/nplants.2015. 221

Rigby H, Smith SR (2014) The nitrogen fertiliser value and other agronomic benefits of industrial biowastes. Nutr Cycl Agroecosyst 98: $137-154$

Rigby H, Clarke BO, Pritchard DL, Meehan B, Beshah F, Smith SR, Porter NA (2016) A critical review of nitrogen mineralization in biosolids-amended soil, the associated fertilizer value for crop production and potential for emissions to the environment. Sci Total Environ 541:1310-1338

Seregin IV, Kozhevnikova AD (2006) Physiological role of nickel and its toxic effects on higher plants. Russ J Plant Physiol 53:257-277

Tiquia SM (2010) Reduction of compost phytotoxicity during the process of decomposition. Chemosphere 79:506-512

Tiquia SM, Tam NF, Hodgkiss IJ (1996) Effects of composting on phytotoxicity of spent pig-manure sawdust litter. Environ Pollut 93: 249-256

Tognetti C, Laos F, Mazzarino MJ, Hernandez MT (2005) Composting vs. vermicomposting: a comparison of end product quality. Compost Sci Util 13:6-13

Visconti F, de Paz JM, Rubio JL (2010) What information does the electrical conductivity of soil water extracts of 1 to 5 ratio $(\mathrm{w} / \mathrm{v})$ provide for soil salinity assessment of agricultural irrigated lands? Geoderma 154:387-397

Wortman SE, Holmes AA, Miernicki E, Knoche K, Pittelkow CM (2017) First-season crop yield response to organic soil amendments: a meta-analysis. Agron J 109:1210-1217

Yazdankhah S, Rudi K, Bernhoft A (2014) Zinc and copper in animal feed - development of resistance and co-resistance to antimicrobial agents in bacteria of animal origin. Microb Ecol Health Dis 25: 25862. https://doi.org/10.3402/mehd.v25.25862

Young BJ, Rizzo PF, Riera NI, Torre VD, López VA, Molina CD, Fernández FE, Crespo DC, Barrena R, Komilis D, Sánchez A (2016) Development of phytotoxicity indexes and their correlation with ecotoxicological, stability and physicochemical parameters during passive composting of poultry manure. Waste Manag 54: 101-109. https://doi.org/10.1016/j.wasman.2016.05.001

Yusuf M, Fariduddin Q, Varshney P, Ahmad A (2012) Salicylic acid minimizes nickel and/or salinity-induced toxicity in Indian mustard (Brassica juncea) through an improved antioxidant system. Environ Sci Pollut Res 19:8-18 